\title{
SURGICAL APPROACH FOR TRAUMATIC RUPTURES OF THE DIAPHRAGM
}

\section{Roman Chirkov, Vladimir Murga ${ }^{\bowtie}$, Famil Babayev, Ivan Vakarchuk}

\author{
Department of Oncology, Surgery and Palliative Medicine \\ Tver State Medical University, Tver, Russia
}

\section{Childtv@mail.ru}

\begin{abstract}
Traumatic ruptures of the diaphragm are characterized by the severity of the clinical course, the complexity of timely diagnosis, the compilation of treatment and high mortality $[1,2,3]$. The intensive growth of trauma over the past decades makes the problem more relevant due to the noticeable increase of the frequency of this pathology $[4,5]$. According to the literature, the number of diaphragm ruptures varies from 0,5 to $6,8 \%$ in the overall structure of blunt combined and multiple trauma of the chest and abdomen $[1,6]$.

During surgery for abdominal injuries tactical errors are made and the rupture of the diaphragm is detected during repeated surgery or autopsy $[1,3]$.
\end{abstract}

KEYW ORDS - trauma, ruptures of the diaphragm, treatment, traumatic diaphragmatic hernias.

\section{OB JECTIVE}

The aim of the work is to determine the optimal algorithms of surgical approach in the treatment of diaphragm trauma and traumatic hernias.

\section{MATERIAL AND METHODS}

The analysis of the features of the clinical picture and diagnostic algorithms in 91 patients with diaphragm injury and 68 with traumatic diaphragmatic hernias was carried out. All patients were treated at the clinical bases of the Department of Oncology, Surgery and Palliative Medicine of Tver State Medical University since 1964 . In most cases $(83,5 \%)$ among the victims were men. The median age was $37.2 \pm 1,7$ years.

\section{RESULTS AND DISCUSSION}

The mechanisms of trauma were the following: car accident trauma $(61.5 \%)$, catatrauma $(20.9 \%)$, a blow to the abdomen (7.7\%), compression of the body between objects $(5.5 \%)$, penetrating injuries (4.4\%). The condition of most of the victims was of medium severity.

All patients were operated under endotracheal intubation anesthesia not later than 7 hours from the moment of admission to the clinic. Laparotomy was the operative access in $78 \%$ of cases. In $22 \%$ of cases a thoracotomy was used when a thoracic or thoracoabdominal injury was suspected.

During the revision of the abdominal and thoracic cavities, a combined lesion of the diaphragm was noted. Hollow organs, liver and spleen were the most frequently affected. In some cases (31.9\%), the most difficult situations were determined by the formation of massive hematomas of the retroperitoneal space due to damage of the vascular wall of a large vessel. In such situations the doctor had to restore the vascular wall and then continue the operation.

In $83.5 \%$ of cases during the revision of the diaphragm surface the lesion was localized on the left side, which can be associated with right-sided localization of the liver. Bilateral lesion was recorded less frequently, which was associated with severe mechanisms of injury of the abdomen, such as car accident trauma, catatrau$\mathrm{ma}$ and abdominothoracic gunshot wounds. The size of the diaphragm ruptures varied in shape and length and ranged from 2 to $40 \mathrm{~cm}$.

In 3.3\% of cases, due to the vastness of the prolapse, it was necessary to proceed the diaphragm plastic intervention using a pericardial flap. In other cases, the diaphragm rupture was possible to be sutured with synthetic thread without tension by a two-row seam. The operation was completed by drainage of the paradiaphragmatic spaces by setting tubular drains to the site of injury. Despite this, in $12 \%$ of cases, the development of purulent complications was noted, which caused in $8.7 \%$ of cases the suture failure with the formation of traumatic diaphragmatic hernias.

Regardless of the nature of the hernia, the treatment of traumatic diaphragmatic hernia is only surgi$\mathrm{cal}$. Scheduled surgery is indicated after a detailed x-ray examination of the patient. Only 42 of the 47 patients with diaphragmatic hernias were operated on. Five patients refused surgery for various reasons.

When choosing surgical access, the time taken from the moment of trauma, the type and location of the hernia were taken into account. Abdominal access, in our opinion, has very limited indications. It can be used in the acute period of trauma before the development of cicatricial changes (adhesions) between the hollow organs and the diaphragm. In the late diagnosis of traumatic diaphragmatic hernias we used thoracotomy access through 6-7 intercostal space due to 
the presence of adhesions between the ectopic organs and the pleura, which cannot be separated through the laparotomy access. Thoracotomy is also indicated in case of injury of the right parts of the diaphragm.

The second important point of surgical intervention is the allocation of organs that have fallen into the thoracic cavity from dense adhesions. Careless manipulations can lead to damage and bleeding due to spleen trauma (in 60 patients).

The third stage of the operation is the return of the fallen organs to the abdominal cavity, which in some cases presents significant difficulties, especially in multiple dislocation. The forced displacement to the abdominal cavity of the stomach and intestine loops leads to the development of paresis in the near postoperative period.

Suturing the hernia gate in the diaphragm is usually not particularly difficult. For these cases, we used thick silk (No. 6), drawing together the edges of the diaphragm. Only in 3 cases it was necessary to apply an additional plastic procedure on the prolapse of the diaphragm using synthetic tissue.

Mortality among patients with strangulated hernias was comparatively high. Eleven people out of 21 patients died (52.4\%). The main causes of death in this group of patients were the necrosis of the colon and stomach wall, purulent pleurisy and peritonitis. It should be noted that in 3 patients with strangulated traumatic diaphragmatic hernia the operation was started with a laparotomy, during which the parietal strangulation of the colon was not established.

\section{CONCLUSIONS}

To this day, the problem of surgical treatment of diaphragm lesions and its complications remains extremely relevant.

If there is a suspicion of the formation of a traumatic hernia in the postoperative period, it is necessary to give preference to the surgical method of treatment. In our opinion, compliance with these positions will help to improve the medical assistance to patients with various injuries of the diaphragm and traumatic diaphragmatic hernias.

\section{REFERENCES:}

1. Aliev SA, Bayramov NIu, Aliev ES. Osobennosti diagnostiki I taktiki khirurgicheskogo lecheniia razryvov diafragmy pri zakrytoi sochetannoi travme grudi i zhivota. Vestnik khirurgii im. I.I. Grekova. 2014. V. 173 , № 4. P. 66-72.

2. Pleknanov A.N. Travmaticheskaia diafragmalnaia gryzha. Vestnik khirurgii im. I.I. Grekova. 2012. V. 171, № 5. P. 107-110.

3. Falidas E., Gourgiotis S., Vlachos K., Villias C. (2015). Delayed presentation of diaphragmatic rupture with stomach herniation and strangulation. Am J Emerg Med, 33 (9), 1329. el-3.

4. Toidze VV, Vasyukova EL, Kaschenko VA, AkiMOV VP, VoLKOV AM. Lecheniie gigantskoi diafragmalnoi gryzhi. Vestnik khirurgii im. I.I. Grekova. 2013. V. 172, № 6. P. 21-25.

5. Lim BL, Teo LT, Chiu MT, Asinas-Tan ML, Seow E. Traumatic diaphragmatic injuries: a retrospective review of the 12-year experience at a tertiary trauma centre. Singapore Med J 2016; 1-16. DOI: 10.11622/ smedj.2016185

6. Thiam O, Konate I, Gueye ML, Toure AO, SECK M, Cisse M. Traumatic diaphragmatic injuries: epidemiological, diagnostic and therapeutic aspects. Springer Plus 2016; 5: 1614. DOI: 10.1186/s40064016-3291-1 